\title{
RICARDO AND THE UTILITARIANS
}

\author{
Sergio Cremaschi
}

In this paper I try to shed fresh light on an old conundrum of Ricardian scholarship, namely: what influence, if any, did James Mill and Bentham exert on Ricardo? The issue has been discussed since the year of Ricardo's death, starting with Mill's obituary, and was still under scrutiny in the last twenty years, among other by Hollander, Hutchison, De Marchi. What I have to add is a reasonable conjecture on the intellectual impact of Ricardo's connection with the Unitarians that may help viewing in new light also at his relationship with Mill and Bentham.

The opinion prevailing in the second half of the twentieth century on the relationship between Ricardo and Bentham has been brilliantly summarized by Guidi as follows: such influence "was limited to philosophical premises and methodological reflection on the nature of political economy, and finally to the rigorous definition of the principles of laisser faire" (Guidi, 1991: 140).

I want to argue that Guidi is right for what he denies and wrong for what he admits of, or that the influence was even more limited and that Ricardo already had worked out his own approach to economic theory when he first met Mill and also that at this time, far from being an "illiterate pater familias", he already had in mind a handful of philosophical ideas learned from independent sources. The dialogue with Mill was important but partly at a tactical level, that of publication policies and involvement in politics, and partly at the level of theory, in a former phase in political economy, but with an uneven relationship due to Ricardo's intellectual superiority, and in a later phase in philosophy and political theory, but also then far from being a pupil-to-master relationship.

\section{The Myth of Ricardo's adhesion to Utilitarianism}

Bowring reported a famous joke by Bentham: "I was the spiritual father of Mill, and Mill was the spiritual father of Ricardo: so that Ricardo was my spiritual grandson" (Bowring, 1843, vol. 10: 498). The joke expresses well Bentham's and Mill's wishes, since they had "adopted" Ricardo while hoping that his economic doctrines, roughly compatible at the practical level with the policies promoted by the Benthamite coterie, would have provided a powerful weapon in the hands of the group. The myth of the existence of "a utilitarian 
school of economists" was so effectively widespread that it came to be believed by both friends and enemies of the utilitarians. A 'Ricardian' economic theory, centred on the principle of population, the iron law of salaries, an anti-rent attitude, and a ferocious Laissez-Faire attitude was being popularised by James Mill and by the Benthamites' Scottish fellow-traveller McCulloch well after it had been revised by Ricardo himself. In fact, it was Mill who invented a kind of "utilitarian economics" or an "economic philosophy", but the relationship between science and philosophy and Mill and Ricardo was almost opposite to the one about which Elie Halévy used to fancy. This was said clearly enough at Halévy's time by Simon Patten, who argued that by "adopting his ideas, Bentham and James Mill really became his disciples" (Patten 1899: 311), but he was ignored while Halévy enjoyed immense popularity in France and also (perhaps as a perverse effect of Lafayette's deeds) on the other side of the Atlantic, where its English translation is still quoted as if it was a still topical piece of scholarship. Patten wrote that Ricardo was an "observer" more than a "reasoner", and that much of his originality derived from the mere fact of being alien to that natural theology based on the Design Argument which had become some kind of a second nature to educated Englishmen, and besides that the "new economic philosophy was the result of a union of the economists with the utilitarians who were led by Bentham and James Mill" (Patten 1899: 310) since they realized it could provide some empirical social analysis to fill in the vacuum in their abstract theories, without which their work "would have resulted in nothing but platitudes if it had not been for a lucky contact with Ricardo and Malthus" (Patten 1899: 310-310). Thus, Patten concludes that it was often said (in 1899)

that Ricardo was a disciple of James Mill, but there is little to prove the assertion. Ricardo had worked out all of his concrete propositions before he met either James Mill or Bentham, with the transformation of economics he had little to do (Patten 1899: 311).

The myth of Ricardo's dependence on Bentham and Mill, originally created for tactical reasons, was transformed into one historiographic fossil and perpetuated by Halévy, just after Patten's attempt at dismantling it, for reasons of a different kind, namely because it fitted well Halévy's own historiographic strategy, meant to celebrate French grandeur by discovering vestiges of Cartesianism where they could not be found. Halévy wrote that "the part played by Benthamism in the evolution of Utilitarian political economy between Adam Smith and Ricardo [...] is generally held to have been an important one" (Halévy 1901-4, vol. 2: 216), and that “James Mill did exert a deep influence on Ricardo's 
intellectual destiny" (Halévy 1901-4, vol. 2: 229). But all this rests on a conjecture. Halévy noted quite correctly that Ricardo's view of economic theory is that of a science of laws and added, also correctly, that the very term law is absent from the Wealth of Nations (Halévy 1901-4, vol. 2: 246)1, but also, quite incorrectly that the very idea of political economy as a science of laws is distinctively French (Halévy 1901-4, vol. 2: 219 ff.); in fact, the word "law" seems to acts for Halévy as a misplaced landmark that leads him astray, hunting for a French connection that would eventually link Ricardo with Cartesianism. And he was wrong, since the link was instead with a different tradition of thought, the one deriving from Joseph Priestley, whose existence he was well-aware, even if he did not suspect the circumstance of Ricardo's contact with that tradition' ${ }^{2}$. Halévy wrote that Mill taught Ricardo the rationalistic Cartesian method he had learned while studying philosophy at Edinburgh with Dugald Stewart (See Halévy 1901-4, vol. 2: $246)^{3}$, and ends up, disappointingly, with the following piece of "evidence": since it is clear that so much of Mill's influence may be found in Ricardo's contribution, "we must admit that Mill, during the long walks he liked to take together with Ricardo, tried primarily to give him lesson on method" (Halévy, 1901-4, vol. 2: 227). One may think, on the opposite, that James Mill's "busy mind" was too filled up with other less abstract concerns, namely political tactics, propaganda, editorial policies, to be left with any spare time for talking methodology.

As a reaction to Halévy's intemperance, Keynes and Schumpeter went too far in the opposite direction, making of Ricardo the first example of a philosophy-free economist; for example, according to Schumpeter, Ricardo was no utilitarian because "that busy and positive mind had no philosophy at all" (Schumpeter 1953: 473); Stigler summarized brilliantly this line of thought by deciding that Ricardo was, in a word, "unphilosophical" (Stigler 1950: 311).

Sraffa shared their view that "there is little doubt that his influence was negligible" on the theory of the Principles (Sraffa 1951, xx-xxi; see also Sraffa 1955, 35), but he went nearer the truth by suggesting that his scientific interests may have had "a more decisive influence on Ricardo's characteristic cast of mind than the teaching of his later mentors, James Mill and Bentham" (Sraffa, 1955: 35). Yet, Sraffa just bordered the truth, since, even if he was the discoverer of Ricardo's relationship with Belsham, he ignored the possible intellectual impact of this connection.

More recently, Hutchison, who believed that Ricardo was an "illiterate pater familias" turned into an economist by James Mill, framed a new version of the view according to 
which the main methodological influence on Ricardo's work was Mill's; in his version, this influence led to apriorism, an attitude that, through Ricardo, came to influence general equilibrium theory and thus most twentieth-century economic theory (See Hutchison 1978: 33-34).

Hollander took an opposite turn: he rightly argued that "James Mill was interested in economic theory as a weapon in the service of his political program" (Hollander 1985: 28) and thus the influence of Mill on Ricardo was inexistent in methodological matters, that Bentham's direct influence was no heavier (Hollander, 1979b), and that Ricardo, far from being an Hutchisonian kind of apriorist was, on the opposite, some kind of taxonomist or sceptical descriptive social theorist. I would say that Hollander is nearly right as a whole, even if his proofs are defective. It is a curious fact that Hollander, who is generally keen on using unpublished evidence such as letters and notes, does not event take note - in several hundred pages - of the existence of a few pieces of apparent evidence for Ricardo's adhesion to "the Bentham and Mill school".

Hutchison's view has been criticised in detail by de Marchi, showing how little apriorism in aware methodological views (as contrasted with polemical or didactical attitudes) may be found in Mill and how little change in Ricardo's scientific style (i.e. in matters such as predilection for mono-causality) may be recognized after his encounter with Mill (See De Marchi 1983).

It may be useful to note that, along with the dogma of Ricardo's a-philosophical mind also the dogma of his a-religious mind was established: according to Stimson and Milgate his plea for religious toleration in Parliament is a clear proof of his atheism (Stimson and Milgate 1991) ${ }^{4}$, apparently for the obvious reason that any believer in any faith is an intolerant fanatic; Henderson argued that Ricardo's Unitarian faith - God knows why verged on atheism (Henderson, 1997: 163), and more recently Depoortère announced that Ricardo's adhesion to Unitarianism - that was at the time a militant sect of religious and political radicals, whose leader had to flee to America in order to escape from lynching - was a fake adhesion, the cheapest way to gain social respectability by ascription to a religious confession whatsoever (Depoortère, 2002) ${ }^{5}$. My impression, when facing the poverty of arguments in favour of Ricardo's a-philosophical and anti-religious attitudes, is that both anti-philosophical scientism and atheism are retrospective identification of Ricardo with his $20^{\text {th }}$ century readers. In other words, these kinds of argument seem to me to amount to the following: how could an intelligent person like Ricardo adhere to any kind of philosophy instead a being "already" some kind of "pure" 
Scientist, and how could he entertain any kind of superstitious belief instead of adhering to the "truth", i.e. Atheism?

2. The true story of the moulding of Ricardo's cast of mind

Ricardo's education was not as completely "neglected" as he sometimes complained (to Mill 12 Sept. 1817. In Ricardo 1951-73, vol. 7: 190), and it is not true that as an adult, "he had his mind to form, he had even his education to commence and to conduct" as Mill wrote in The Morning Chronicle in 1823 (See Bain 1882: 212; see also Henderson 1995: 142-3).

Ricardo's complaint should not be taken literally, as if it were a sentence form an 'objective' report on Ricardo's biography instead of a causal remark from a piece of correspondence; it should be read instead within the context of ac speech act; the speech Ricardo was performing was expressing his respect to people who had a University education at Edinburgh, the Athens of the North, like James Mill, but also such moves by Ricardo are always ambivalent, since they are respectful (but perhaps ironical) ways of shifting the burden of proof on Mill.

Also, Mill's statement should not be read as disinterest report oh historical truth, and in fact Moses's Ricardo's obituary reacts somewhat harshly to Mill's 'truth'. The speech act Mill was performing was boasting. He was magnifying his own role as advisor and mentor of such an important thinker as Ricardo was now recognized to have been and disparaging the education received by the ruling elite at Cambridge and Oxford (note that John Stuart Mill did not attend a University). Ricardo's education, even if it was that of somebody who could not have been admitted to Oxford and Cambridge where only members of the Church of England were accepted, it was probably an unusual education, such as a Jew from a wealthy family could receive in London in the last decades of the eighteenth century, and by the mere fact of turning him into an outsider contributed in moulding Ricardo's mind, making him a man "from another planet" (Ricardo, 1951-73, vol. 5: 56; cf vol. 5: 85).

The universally ignored influence on Ricardo's mind is the teachings of Unitarian theologians ${ }^{6}$. The fact that Ricardo 'converted' to the sect of the Unitarians was reestablished by Sraffa. The fact should be better restated as the circumstance that he became a sympathizer, probably without any Baptism and any formal refusal of the Jewish faith. Staffa could hardly be said to have overstressed the implications of this fact. 
On the contrary, the importance of the Unitarian literature in the English intellectual scene of those decades was not unknown to Halévy (1901, vol. 3: 239 ff.), but what he did not suspect was the fact of Ricardo's adhesion to Unitarianism.

Thomas Belsham, the Minister whose Ricardo was the hearer for more than two decades, was the author of a treatise, Elements of the Philosophy of the Mind that drew inspiration mainly from Hartley and Priestley and was often critical of Dugald Stewart. He argued for:

(i) a separation of scientific terminology and ordinary language;

(ii) a view of knowledge as never reaching the "real" essence of any substance;

(iii) a view of the "moral sciences" opposite to Dugald Stewart's view, namely the idea that "as moral ideas are equally capable of strict definition with mathematical ideas, demonstration is equally applicable to moral subjects" and that the reasoning on the behaviour of voluntary agents may reach the same degree of precision as "that with which we foretell the effects of physical causes";

(iv) a view of the science of politics as a part of the philosophy of mind, providing the ruler with "a profound knowledge of human nature" and teaching him "how to guide the various passions and contending interests of parties, and of individuals, to the general good";

(v) a version of Newton's rules which omits the fourth rule, the one emphasized by Hume and the Scots, that stresses a demand for empirical constraints on theories (see Cremaschi and Dascal 1996; Cremaschi 1999).

(vi) a 'solution' to the problem of theodicy that was something less than optimistic.

It is an interesting coincidence is that the first publication by Mill on a philosophical topic was a review of Belsham's book where he attacks him almost on everything, defending Locke against Belsham, defending Reid against Hartley ${ }^{7}$. There is enough to prove that Mill held Belsham in low esteem, no less than Malthus, and we might conjecture that Belsham is never mentioned in Ricardo's correspondence with Mill not because he had become unimportant in Ricardo's life, but simply because it was well-advised not to provoke Mill.

The last point, that is, theodicy, deserves comment. Deportee (2002) unmasked Ricardo's fake adhesion to Unitarianism starting with the decisive argument that Ricardo rejected Priestley's quasi-Leibnizian optimistic solution to the problem of evil. I have argued that, on the contrary, Ricardo in his correspondence with Mill argued a claim, namely the difficulty of providing any solution to the problem of evil, that was precisely the same point argued for in print a few years later by Thomas Belsham himself (see Cremaschi and Dascal 2002). The most significant of Ricardo's philosophical readings about which he 
commented in his correspondence with Mill, seems to have been Pierre Bayle, and in fact long abstracts from his Dictionnaire and Pensées Diverses are copied in his commonplace books (See Ricardo 1951-73, vol. 10: 394). Ricardo notes that Bayle points out the difficulty to "account for evil in a world governed by a Being of unbounded benevolence" (to Mill 9 Nov. 1817. In Ricardo 1951-73, vol. 7: 206). This is no proof of Ricardo's atheism, and Bayle was no atheist as he was believed to have been by nineteenth-century secularist hagiography. Instead, Ricardo's interest for Bayle had much to do with the teachings of the Unitarian divines. In fact, evil was one of the chief theological concerns of both Priestley and Belsham. Thomas Belsham believed that the fact "that evil, natural and moral, is unavoidable in the works of God, is a problem of very difficult solution" (Belsham 1826-7, vol. 2: 37); if we consider the world as a whole, "we see enough" to be satisfied "that the result of it is a great preponderance of good [...] but when we consider the divine dispensations in detail, we [...] discover that they are far beyond the reach of human sagacity" (Belsham 1826-7, vol. 2: 36-7).

This kind of long-run optimism immunized to every practical effect by dismal pessimism on the short run sounds strangely familiar to any reader of Ricardo the economist.

\section{The true story of Ricardo's adhesion to the party of the "Philosophic Radicals"}

The phenomenon of alliance between Benthamites and Unitarians in the name of practical reformist battles was not limited to Ricardo. The phenomenon was extended later to members of less radical religious groups, such as evangelical Christians and even progressive Anglicans such as John Bowring, Bentham's editor. In fact the "Philosophic Radicals" were not a sect of utilitarians or of followers of Bentham's doctrines; they were a merge of groups and individuals with different backgrounds who had to redefine their political allegiances in the period of sudden political and social changes following the close of Napoleonic wars; "philosophical" did not mean inspired by one defined philosophy (such as Bentham's) but "rational"; in other words, the adversary was first Whig radicalism, with its intellectual legacy carrying the rights of man and the right of resistance, and then French-style Jacobinism (See Thomas 1979).

The decisive fact, in order to locate the true character of Mill's relationship to all kinds of reformers, and thus also to Ricardo, is that James Mill "invented" the Benthamite coterie or the Philosophic Radicals as a weapon for practical political goals, not as a learned society. These were enlightened battles such as reform of the received systems of 
political representation, religious toleration, abolition of slavery, and more questionable ones such as abolition of poor laws etc. Allies were taken where they could be found, without asking them any certificate of ideological purity: for example, Quakers were committed anti-slavery militants, and Roman Catholics, in Britain could become, for rather obvious reasons, allies in a campaign for religious toleration. Brougham recalls as the most notable aspect of Ricardo's activity in Parliament, not his speeches on economic issues, but instead "his extreme opinions upon questions connected with the reform of the constitution in Church and State" (Brougham 1839: xxxiv). In fact, Ricardo's first intervention in Parliamentary life was a speech in support of a petition for religious toleration signed first by Robert Aspland, one of Ricardo's Unitarian Ministers, and in the correspondence he defends Aspland's idea, opposite to Locke's, that toleration should be extended also to atheists (Ricardo to Mill 9 Sept 1821, Ricardo 1951-73, vol. 9: 60; Ricardo to Goldsmit 4 April 1823, Ibid: 278). Religious toleration was the prime goal, and indeed the very reason d'être of the Unitarians, and it had been the banner of reasonable Christianity since the times of John Locke, Fausto Sozzini (the founder of Socinianism, the wider anti-Trinitarian trend that includes English Unitarianism) and then Pierre Bayle, and after them Joseph Priestley, Robert Aspland, and Thomas Belsham, the English Unitarians leaders.

\section{Ricardo and the "Bentham and Mill school" on methodology}

On one occasion Ricardo apparently declared his own adhesion to "the Bentham and Mill school" in matters of methodology. In 1823, that is after he wrote the Principles and after the systematic philosophical readings he carried out after competing his main work and before entering the Parliament, he wrote to Maria Edgeworth: "I like the formal method, after the manner of Bentham and Mill" (to Maria Edgeworth 11 Jan. 1823. In Ricardo 1951-73, vol. 9: 259). Also here, the apparently clear statement, that may be used by a naive historian as evidence in need of no interpretation, should be read as the content of a speech act, and the kind of speech act is decisive in order to understand the real meaning of the statement. Here, the real content turns out to be precisely the opposite of the naive historian's reading. In fact, if we look at the context of the conversation and at the moves in the conversation itself after the utterance of such a statement, we find that the conversation was a semi-serious one about potatoe-floor as a viable alternative to wheat in order to prevent famines and that after his apparent declaration of philosophical 
allegiance to Benthamism, Ricardo went on present his argument as a list of points marked by numbers. The "formal method" turns out to be not any kind of methodology, as the term is presently understood, but Mill's "art of laying down your thoughts, in the way most easy to apprehension" (ibid.), an art that Mill himself had strenuously tied to inculcate in Ricard0's mind when he was beginning to write the Principles. In other words, Ricardo was poking fun at James Mill's ambitions of a would-be mentor.

Had Ricardo real occasions to be exposed to Bentham's and Mill ideas on the theory of knowledge and method? On language and method, Bentham had his own theory of language based on nominalism and conventionalism ${ }^{8}$. But almost everything of Bentham's writings on language remained unknown until the twentieth century. There is no proof of Ricardo's acquaintance with Bentham's work in this field and the warm friendship that developed among them in the last years of Ricardo's life, their conversations were dedicated to politics and Reform, not to philosophy, a field where Bentham, unlike Mill, never aspired to the role of a mentor; besides, we know that Bentham did not like to discuss his doctrines, on which he used to concentrate only while writing, or better dictating, his own manuscripts (Mill 1835: 123).

One important detail is that such ideas could also not have been absorbed by Ricardo through Mill. It is but too clear that no trace of these ideas may be found in Mill's published or unpublished writings, where he sticks to the Scottish philosophy he had learned from Dugald Stewart. Did Mill teach Ricardo any other kind of philosophical ideas? Did he teach him a Method, Cartesian rationalistic apriorism learned through Dugald Stewart, as Halévy fancied in order to indulge in national pride, and Hutchinson repeated a few decades later, albeit only in order to complain of such disgraceful circumstance? A balanced answer has been given by de Marchi (1983) several years ago and I will be bound almost to repeat what he forcefully proved.

Halévy made three generations of economists believe that James Mill was endowed with

A genius for deduction and logical presentation that gives his words some kind of originality, even when he was expressing the ideas of others (Halévy 1901-4, vol. 2: 186-7).

Now that the edition of Mill's Collected Works had made his writings more easily available, a more disenchanted first-hand appraisal is possible. Mill did enjoy the enviable asset of having had an education at the best British University, namely at Edinburgh, and with the best academic philosopher of the time, Dugald Stewart. He came to London with the valuable viaticum of Stewart's teaching, and for several years he had no other chance 
of improving on that dowry, except by unsystematic omnivorous reading such as his activity as a writer for newspapers occasioned him to carry out, and by exposal to Bentham's ideas as his activity as on of Bentham's editor and as the main organizer of the practical undertakings of the Benthamite lobby gave him occasion to carry out. From Bentham's enormous hoard, he took basically three items: the principle of utility, the doctrine of pleasure and pain as motives for action, a doctrine of government based on the natural opposition of the interests of the ruled many and the ruling few. These items were added to Dugald Stewart's philosophy with no attempt at a new synthesis, for which Mill had not enough time, motivation, and intellectual gifts.

As soon as Bentham's financial support gave him an opportunity to engage in more demanding intellectual enterprises, he started the History of British India. This is no example of a Benthamite work, nor is it a display of a doctrinaire Cartesian spirit, as Halévy believed and made believe. On the contrary, the mediocrity of the overall performance notwithstanding, it is an example of the Scottish genre of "conjectural history" following the path broken by David Hume, Adam Smith, Adam Ferguson, and John Millar. This was based on a science of human nature as a source of principles (such as association of idea, imagination, sympathy, self-deception, self-interest) applied to the explanation of historical facts when documented or used for building conjectures on possible paths of social evolution, when evidence was lacking. This was far from being inspired by apriorism and rationalism but was inspired on the contrary by an empirical and hypothetical approach. Mill declared that theory may not be distinguished from so-called "practice" since "good abstract principles are neither more nor less than the accurate results of experience, presented in an exceedingly condensed and concentrated state (Mill 1813: 412). The conjectural history was immunized from experience, by the room it made for hypotheses, but was far from being a kind of doctrinaire apriorism, in so far as it allowed for a principle of - let me say - un-determination of social events due to "friction". This is an idea taught by Stewart who used to insist on the role of such a disturbing factor as the main reason why societies are not perfectly analogous to machines, and even if their functioning obeys to laws, the effects of such laws are not always certain and constant. Mill writes that "the general laws of human nature" may receive individual or general variations and we should take the effect of "friction" into account in our predictions and explanations.

In the History of British India, a book that is not directly didactic nor polemical, we may see at work at his best what de Marchi called James Mill I, that is a comparatively open- 
minded, un-dogmatic, non apriorist thinker. This is the kind of an author one may easily find also in Mill's sparse articles and reviews in journals and in the Analysis of the Phenomena of the Human Mind.

The latter is the most philosophical writing by Mill, and yet it contains very few Benthamite ideas; indeed, the associationist psychology it presents is in the spirit of the Scottish philosophy after Stewart, when it was concentrating on the philosophy of mind (besides quickly declining from the high level of its former achievements), apart from some Benthamite emphasis on the role of pleasure and pain as springs of action.

The other face of Mill, what de Marchi calls James Mill II, that has led Halévy and many readers after him astray, is the quite different look of polemical or militant works such as $A$ Fragment on MacIntosh and the Essay on Government, or of didactic works such as The Principles of Political Economy. James Mill II is an author who tends to simplify, to deduce consequences from one principle, besides being extremely polemical. This is a duality in Mill's character that has been illustrated at length by his son in his own autobiography, but it is worth pointing out that it had to do with Mill's temperament and with his selfunderstanding of a remarkable part of his intellectual enterprises, namely, not as disinterested search for truth but as militant activity in view of Reform. In the didactic and militant works, even of the Scottish legacy did not encourage apriorism and antiHistoricism of the kind favoured by Bentham, Mill felt entitled to employ a "didactic method" that was inspired by Euclid, or a deduction from principles taken as granted of a number of particular propositions, that is "synthetic" procedure, that was legitimated by the assumption that the "analysis" aimed at discovering principles had been already carried out elsewhere. This is a method described by Adam Smith (Smith 1983: 132-4), even if Adam Smith was no Cartesian rationalist. The issue was one of style of presentation, not of theory of knowledge. In a word, the doctrinaire mood that Ricardian economics seems to take in Mill's Elements, is a matter of pedagogy and political propaganda, not of faith in a priori general laws derived from a French influence received through a non-existing French-Scottish connection. This mood, mistaken for a "Ricardian vice" by Schumpeter, depends on an aware didactic and political choice made by Mill, the choice of ignoring objections and dubious points, of not disclosing to a wider public any disagreement among specialists, of discrediting those of the specialists who disagreed on any "truth" that looked important for political battles, of not going into the most refined theoretical points, but choosing instead to stress the "results" of the "science" of Political economy as points about which no disagreement from possible, in order to persuade the 
wider public of the existence of a body of laws about which there was a firm consent among all the specialists who were true thinkers, not lackeys of the aristocracy.

Ricardo was not sanguine about discussion of methodological issues in print, but he repeatedly discussed points of language and method in his correspondence and manuscript notes. An alternative source for his ideas on language and logic is Belsham's views on language, derived from Priestley (See Cremaschi and Dascal 1996, 1999b). This view is strikingly similar to Bentham's views on a few points, and to Dugald Stewart's on other points. It may be such a view what lies behind the charges he levels at Malthus of "sometimes attaching one meaning" to words and "sometimes another" (to Mill, 1 Jan. 1821. In Ricardo 1951-73, vol. 8: 331), his aversion to disputes on words (to Malthus, 4 Sept. 1820. In Ricardo 1951-73, vol. 8: 228; cf. to Place 1 Nov. 1819. In Ricardo 1951-73, vol. 8: 121), but also - it is worth noting - the criticism he addressed to Mill at an early stage, of not being consistent on matters of meaning and definitions. As soon as 1811 Ricardo criticizes Mill for lack of explicit definitions: "You have no where defined the word value" (Ricardo to Mill 26 Sept 1811: In Ricardo 1951-73, vol. 6: 54).

\section{Ricardo and the "Bentham and Mill school" on ethics and politics}

On other occasions Ricardo apparently declared his adhesion to Benthamism as an ethical doctrine.

But these professions go with explicit criticisms to the main point of Benthamite utilitarianism. Ricardo's objection to a point made by Mill in his History of British India, namely that a country is civilised in so far as its institutions are subservient to the doctrine of utility, not to superstitions (Mill 1817, vol. 3), is that the felicific calculus cannot be applied because objects of desire, or sources of happiness, are incomparable. He writes:

The difficulty of the doctrine of expediency or utility is how to balance one object of utility against another there being no standard in nature, it must vary with the tastes, the passions and the habits of mankind (to Mill 6 Jan 1818. In Ricardo 1951-73, vol. 7: 242).

Note the kind of speech act Ricardo is performing again: he goes writing: "This is one of the subjects on which I require to be enlightened" (Ibid.). Here again a naïve historian may read in this sentence a report of an objective fact: that Ricardo's relationship to Mill was a pupil to master one. On the contrary, a pragmatic Gricean interpretation of the text yields the opposite result: Ricardo was as always shifting the burden of proof on the 
partner, like sceptics systematically do, and perhaps was even poking fun at Mill with that kind of subtle irony that no Calvinist would ever be able even to sense ${ }^{9}$.

What Ricardo was not prepared to accept is the possibility to measure happiness and to compare units of utility with each other. The sore point was the possibility to measure happiness, a problem that worried him in his Notes to Malthus and in a few letters to Malthus himself (See to Malthus 4 Sept 1817. In Ricardo 1951-73, vol. 7: 185). The problem was still almost the same at the end of his life when he was struggling with in his attempts at finding an invariable measure of value. And the problem was already there in the first edition of the Principles where he wrote that

One set of necessaries and conveniences admits of no comparison with another set; value in use cannot be measured by any known standard; it is differently estimated by different persons (In Ricardo 1951-73, vol. 1: 429).

As a whole, the problem was not one that a dogmatic rationalist could easily put forth; it arouse out of the doubts of a moderate sceptic, such as a disciple of Priestley and Belsham could have been.

Let us come to apparent professions of adhesion to Benthamism. In a letter to Place, Ricardo defends Malthus on population while trying to show that his use of the words right and law of nature amounts roughly to utility or the good of the whole, and adds, in order to stress his distance from Malthus and his closeness to Place that "I as well as you am a disciple of the Bentham and Mill school" (to Place 9 Sept. 1821. In Ricardo 1951-73, vol. 9: 52). This statement yet may be read as a concession made to a partner in the conversation in order to stress points of convergence and try to gain his assent on other points. Here what is conceded is that law of nature and right are strictly understood meaningless words and that "moral right" or "the good of the whole" on the opposite are meaningful terms. This is much less than professing adhesion to the moral philosophy of Bentham in all its implications, and could be admitted on the basis of Belsham's ethics, that was basically a kind of intuitionism like that professed by Priestley, but made room also for theological consequentialism as a subordinate view trying to reconcile both views. In short Belsham taught that the only valuable end of human life is happiness (Belsham 1801: 369); the essence of virtue is the tendency of an action to the agent's ultimate happiness, but virtue is "voluntary production of the greatest sum of happiness or [...] unlimited benevolence" (Belsham 1801: 379) and self-denial is part of virtue in its utmost degree; doctrines making virtue consist in utility are right in so far as they understand it as 
production of universal greatest happiness, but are wrong in so far as they identify it with utility of any partial group; thus the criterion of utility may be accepted as a moral criterion only when applied in totally universal terms, since only at this level there is coincidence between the agent's ultimate happiness and "general good" (Belsham 1801: 432). And thus

Virtue is productive of the agent's greatest happiness only if the word is ruled by a benevolent and wise author. Self-love and benevolence may be reconciled only through religion (Belsham 1801: 411) ${ }^{10}$.

This quote may be enough to prove that when somebody in the first decades of the nineteenth century was mentioning "the greatest happiness" he needed not be a Benthamite and could have heard about it from other sources. And in case somebody had been hearing Sunday sermons by the author of the above quote for more than 25 years when he used the phrase, one may safely think that he need not be a Benthamite at all. Let's come now to Ricardo's infamous use of the phrase.

In a letter to Maria Edgeworth, Ricardo seems to make a much more binding profession of adhesion to Benthamite ethics than that made in the letter to Place (to Maria Edgeworth 13 Dec. 1822. In Ricardo 1951-73, vol. 9: 239). He writes that he is not sure that potatoes afford a more safe and abundant provision of food, and thus that they may ensure more happiness for more people with safety (that is, without risks of famine for one year in six or seven, and he adds. "Give me these securities and I will fight with you till death in favor of the potatoe, for my motto, after Mr. Bentham, is 'the greatest happiness to the greatest number'” (Ibid.: 238-9).

The remark is in order here that the motto is not quoted literally but reinterpreted freely. Besides no mention is made here of Bentham's philosophy as a whole. The problem Ricardo had in mind in the letter seems to be certainty of happiness and the comparatively heavier weight to ascribe to risk of unhappiness, that is, difficulties Bentham's felicific calculus meets. This is precisely the opposite of what the supporters of Ricardo's Benthamism have found in this quote. Ricardo had written before:

The argument, that the failure of the potatoe crop is only occasional, and that at all other times there will be in the world a much greater number of happy and contented beings, appears to me defective. Judging by my own feelings, if for five, six, or seven years of easy competency, with respect to food, I had to endure 
one year of famine, and to witness the sufferings of my family and friends for that one dreadful year, I would rather that I had never been born (Ibid.: 238).

To sum up: Ricardo's occasional use of a supposedly Benthamite phrase should neither be ignored, nor read literally, since such utterances cannot be read as the ultimate truth about what Ricardo was effectively doing, but instead show up as moves in a dialogue with one specific interlocutor he wanted to convince, or to which he wanted to concede some point in order to deny some other, or with whom he wanted even to poke fun at Bentham and Mill as when he mentioned the formal method. Thus, paradoxical as this may seem, the utterance "I am a disciple of the Bentham and Mill school" is not to be read literally, since Ricardo was not writing an entry about himself for an encyclopaedia but was engaged instead in a conversation; and the full meaning of a speech-act in a conversation may be reconstructed only from the context. In this case the utterance may have several Gricean implicatures (i.e. things that are said tacitly, not by logical implication, but relying on the partner's background knowledge, on what has already been said during the previous part of the conversation, on the partner's ability to understand what kind of speech act is being performed) ${ }^{11}$ such as:

a) I am a (critical) disciple or fellow-traveller;

b) I know Bentham's doctrine well and I have competent objections to make;

c) I agree with Bentham on the principle of the greatest happiness (vs. natural law) even if I don't agree on the very idea of utility as a viable empirical entity, as well as on that of a felicific calculus.

Was this the argument of a Benthamite or of one of the critics of Bentham? I opt for the latter answer. This is made more plausible by the availability of an alternative account for the origins of a number quasi-Benthamite doctrines shared by Ricardo, namely the teachings of Priestley and Belsham. Ricardo's opinions on ethical and political issues may be made to depend on the kind of intuitionism with theological consequentialism which Ricardo had learned from the Unitarian minister Thomas Belsham. In this way I may account for his professing adhesion to the greatest happiness principle without being a Benthamite.

Let us come to Mill. Could Ricardo have learned an ethic from his would-be mentor? Mill was actually interested in politics and economics, something less in religion (in terms of an enemy to fight), and even less in ethics. He published in 1835, twelve years after Ricardo's death, a polemical tract on ethics, where he defended Benthamite ethics, with much vehemence and - to say the least - without much depth and interest, limiting 
himself to defending the principle of utility with a number of arguments, recurring very often to the tu-quoque argumentative move, that is, trying to prove that utilitarian ethics says what any reasonable moralist should say and accordingly all serious philosophers of the have been saying (Mill 1835).

He contributed something more original to political theory. In the Essay on Government he presented a theory based on Bentham's few-may framework and tried to prove that the remedy for the evils of bad government is social engineering employed in order to make the interests of the many and those of the few coincide (Mill 1818). Yet, also on this doctrine we have evidence of a critical attitude by Ricardo. He expressed disagreement with Mill on one of the most basic assumptions of Benthamite politics and of the psychology underlying it, namely the role of "self-interest" or "self-preferment". He writes that wealth and power are not "the only things desirable to man" and that instead "public opinion and public sympathy" are much valued by all ranks of men, and accordingly "sufficient motives exist for the acquirement of knowledge and talent independent of the power and money which they may chance to bring along with them" (Ricardo to Mill 30 Dec 1817, Ricardo 1951-73, vol. 7: 238-9).

We may conclude, in John Bonner's words that

while Ricardo was a friend and admirer of Bentham, his acceptance of the general objective of 'the greatest happiness of the greater number' was little more than a gesture to what he found uncontroversial and vaguely comprehensive. He never bothered with the details nor made any contribution to the development of the utilitarian creed (Bonner 1995: 2)

\section{Ricardo, Mill, Bentham on economics}

Towards the end of 1810 Mill sent to Ricardo a manuscript by Dumont resulting from editing of a number Bentham's papers on currency that had been written about 10 years earlier. Ricardo wrote very detailed remarks on Mill's request and ended up by expressing an opinion against publication.

The comment of greatest interest is that to chapter 5, where Bentham-Dumont writes:

Toute valeur est fondée sur l'utilité, sur l'usage qu'on peut faire de la chose. Point d'usage point de valeur. Ainsi comme c'est toujours sous le rapport de subsistance, de défense ou de jouissance qu'un article de la matière de la richesse peut avoir son usage, c'est aussi sous ces mêmes points de vue qu'il a une valeur (Ricardo 1953 284). 
Bentham goes on arguing that paper money has a value deriving from convention, but this value derives eventually from that of bullion, which is an intrinsic value, or a kind of value in use.

Ricardo's comment is:

I like the distinction which Adam Smith makes between value in use and value in exchange. According to that opinion utility is not the measure of value (Ibid.).

Even though it is clear that Bentham did not introduce a theory of subjective value in his overall economic work, and this is the reason why the father of utilitarianism never was a "utilitarian" economist (See Guidi 1991; Bonner 1995), in this passage he was hinting precisely to that direction of inquiry. Ricardo's objection seems to be based precisely on a refusal of any other theory of value than a cost of production theory.

Rizvi (1992) has argued that Ricardo had two basic arguments against utility as a basis for value: a) the triviality of any account of value based on utility, since any kind of exchange value presupposes utility to the same extent, and accordingly the real scientific issue is whether different cost of production may account fro different value or also another causal factor, scarcity, need be taken into account; b) the impossibility of measuring utility, that is one recurrent objection expressed in the last years of Ricardo's life. These arguments fit well with Ricardo's reaction to this point of Bentham's contribution to monetary theory. In fact, in the Notes on Mr. Malthus Ricardo declares that happiness is directly correspondent to the abundance of material goods needs by human beings (Ricardo 1928, note 8 ). This amounts to saying that there is no room for utility, and that there is no way to measure neither utility nor happiness apart from measurement of value of commodities (which is a different thing).

Let me add that in the third edition of the Principles the definition of measurement given by Destutt de Tracy's in his Eléments $d^{\prime}$ idéologie is quoted approvingly (having in mind the quest for an invariable measure of value); Ricardo adds that he regrets however that Destutt de Tracy had shared Say's mistaken definition that makes "value", "wealth", and "utility" coincide, where utility should be kept distinguished form value (Ricardo 1951-73, I: $284 \mathrm{fn})$.

Is there a Benthamite influence may lie at the root of Ricardo's theory of rent? This is a hypothesis explored by Hollander (1979b). Ricardo may have taken the essence of his theory of rent from a lost paper by Bentham himself, where he could have developed suggestions that may be found in several of Bentham's economic writings. Hollander's 
answer is open. In fact, Ricardo may have taken the theory of rent from several sources, including Malthus and Mill ${ }^{12}$. Let me note also that this point of Bentham's economic contribution is a typical "classical" doctrine, not connected in any way with Bentham's distinctive philosophical doctrines. Like most of Bentham's economics also this piece was non-Benthamite economics ${ }^{13}$.

Thus, Ricardo owed almost nothing to Bentham in economics, not even method, Halévy notwithstanding. He owed slightly more to Mill but, Ricardo's modesty and Mill's arrogance notwithstanding, more in matters of editing, editorial policies, and psychological support.

Sraffa concluded that

Mill's contribution to the making of the Principles was less than might have been expected from his promises and encouragement. On the theory there is little doubt that the influence was negligible [...] Mill's letters of the period are full of advice relating to 'the art of laying down your thoughts, in the way most easy to apprehension'. But despite his repeated assurance that he would see the order and arrangement [...] in the main the sequence of topics has been left as Ricardo had originally worked through them (Sraffa, 1955: $x x-x x i)$.

6. Bentham and Mill's influence on Ricardo: more practical than intellectual The relationship with Mill was believed by Moses Ricardo to have been the most influential in David Ricardo's life (See Moses Ricardo 1823) and Halévy was right in saying that "all acts in Ricardo's life have all been the result of Mill's will" (Halévy 1901-4, vol. 2: 217). In fact, James Mill did have an impact on Ricardo, but more in those 'practical' matters (style of composition, publishing policies, and direct engagement in politics) in which he was really interested than in matters of "method", as fancied by Halévy.

Mill did also interact with Ricardo also on strictly intellectual matters but it hard to say that it was a master-pupil relationship. Hollander has been nearly right in stressing that the relationship was at a different level: that Ricardo got in touch with the Benthamite coterie only after he had already begun to write on economic subjects, and indeed had already elaborated his main doctrines (Hollander 1985, I: 15-36). De Marchi concluded that it is "unlikely that James Mill tutored Ricardo in method. And whether Ricardo's method was in any serious sense a formative influence in modern general equilibrium analysis is far from clear" (de Marchi 1983: 175). 
After Ricardo had completed his Principles, Mill started with a view at preparing him to his activity in Parliament, teaching him the "science of legislation", whose political economy was believed to be a part (See Collini, Winch and Burrow 1983: 115-116). He made intensive philosophical readings, partly based on reading lists handed on to him by Mill (Cremaschi and Dascal, 1996). Mill's History of India, was part of this reading, and Mill thought, with his usual lack of modesty, that it could be "no bad introduction" to the science of legislation (Ricardo 1951-73, vol. 6: 195; cf. 231). Ricardo was highly appreciative of this work, and yet, it is was not a Benthamite work. The science that Mill believed he was in a position to teach Ricardo was a new science, one of the nineteenth century philosopher's stone, different from jurisprudence, that "investigates the means which are best for the protection of rights. It does not determine what ought to be rights, and what ought not; or what is that distribution of powers, which is most conducive to the happiness of mankind upon the whole. That belongs to the science of legislation, wholly distinct from that of jurisprudence" (Mill 1835: 145).

In the years between the first edition of the Principles and the beginning of his parliamentary activity, Ricardo made massive philosophical and historical readings. He followed suggestions by Mill, but his reading was not limited to these suggestions and he showed independence of judgement. From the correspondence we know that he read Locke's Essay but was not enthusiastic about the topic, i.e. philosophy of mind and the theory of knowledge (to Mill, 9 Nov. 1817. In Ricardo 1951-73, vol. 7: 206), that he read Hume, Bacon, Dugald Stewart, Reid, Berkeley, Warburton, Beattie (the anti-sceptic enemies of Hume), and Montesquieu and Millar (to Mill, 19 Oct. 1817; 12 Aug. 1818. In Ricardo 1951-73, vol. 7: 196; 277-78), but his favourite reading became Bayle, a sceptic fideist Christian who distrusted theologians and believed that the problem of evil admitted of no solution. Such readings were made after the first edition of the Principles, thus Mill could not have taught Ricardo a method for writing the Principles; besides, such a reading list, that was not completely made by Mill, was not the best way for schooling a would-be doctrinaire rationalist social thinker, not to say a utilitarian economist, but instead could make for the library of a moderate sceptic and an empirical and historical social thinker.

Something may be added on a possible gradual change in Ricardo's attitude to Mill (in strictly intellectual matters; their friendship was always beyond any doubt). In the correspondence with Mill, in a first phase, the reader meets Ricardo defending Mill a rigid view of the principle of population and hard-line policies on poor relief during famines (Ricardo to Mill 17 Nov 1816, Ricardo 1951-73 vol. 7: 90). In the last years - that is, after 
his philosophical readings which included Bayle and the Scottish philosophers, and occasioned his declarations concerning he difficulty of solving the problem of evil - when he wrote the machinery chapter, he seems to have had an evolution similar to Malthus's evolution, namely from a more absolute to a less absolute character of economic laws (see Davis 1989). In those years we meet apparently growing awareness by Ricardo of Mill's dogmatic attitude in almost every field, ranging from value theory to population. On one occasion he defended the views of opponents of the principle of population against Mill (See to Mill. Enclosure: Ricardo's Notes on Mill's "Elements of Political Economy" 18 Dec. 1821. In Ricardo 1951-73, vol. 9: 126)14. It is worth noting that McCulloch immediately perceived this change and reacted harshly precisely for the same reasons as Mill was not favourable to such admissions: because disclosing to the public the existence of doubts and dissent among economists was dangerous to the cause of "science" as contrasted with prejudice (See McCulloch to Ricardo, 5 Jun. 1821. In Ricardo 1951-73, vol. 9: 382).

In the story of the practical influence on Ricardo, also Bentham played a direct part. After Ricardo was elected to Parliament, they started meeting regularly together with Mill, having long walks in London's parks during which Ricardo used to update Bentham about parliamentary activities. This kind of informal contacts were part of the intense activity of the Benthamite lobby, which included people with various backgrounds who shared a number strategic objectives such as a less oligarchic electoral system, abolition of the Poor Laws and of the Corn Laws, and religious toleration.

This point made the subject of Ricardo's first parliamentary speech. The speech was in favour of a petition for religious liberty whose first signature was that of Robert Aspland, one of the three leaders of English Unitarianism along with Priestley and Belsham. This speech by Ricardo, that Milgate, Stimson, and Depoortère, for unknown reasons, believe to be a clear proof of atheism, is instead the final proof that Ricardo, even in his political activity, was never a puppet in Bentham's and Mill's hands, and besides that that the practical battles of the Benthamites were more those of a heterogeneous alignment of friends of reason than those of a tightly organized politico-philosophical group.

\section{Conclusion}

Ricardo owed little to Bentham and Mill in philosophy; he owed almost nothing to Bentham in economics and, Halévy and Hutchison notwithstanding, he owed not very 
much even to Mill; what he owed had little to do with method. Ricardo's debt was heavy in matters of publishing policies, psychological support, involvement in party politics, and somewhat less heavy in matters of editing and suggestions for reading.

Let me summarize the conclusions that seem to be suggested by my argument:

(i) Ricardo was not "unphilosophical" (pace Hutchison, Stigler, and Schumpeter);

(ii) Yet, he was not a follower of Bentham and Mill in philosophy;

(iv) he was a fellow-traveller of the Benthamites in practical and political issues; he was a supporter of religious toleration, because he was a rationalist Christian, a supporter of a democratic electoral system but not on utilitarian grounds, and - Bentham and Mill notwithstanding - towards the end of his life, became a supporter of the interests of the working class;

(v) in the theory of knowledge, he had learned from Belsham a kind of moderate partial scepticism, together with a theory of scientific language as an artificial language, and of scientific theories as unrealistic idealizations;

(vii) in ethics he had learned a kind of combination of intuitionism with theological consequentialism that made room for the principle of the greatest happiness, but on grounds different from those of Bentham;

(viii) in economics he tried to unify and simplify Adam Smith's theory, looking for 'laws' instead of causes because of scepticism about the possibility of a real knowledge of causes, and looking for simplicity because of scepticism about realism of assumptions, following precisely the methodological precepts of Priestley he had learned from Belsham;

(ix) in value theory he never tried to base value on utility, trying instead to relegate utility in the limbo of universal preconditions of value, and thus tried to make it

(x) there was a possible influence of Bentham only the theory of rent, but this was not something specifically utilitarian and could have been taken also from other sources; the influence of Mill on Ricardo was inexistent in economics; the influence of utilitarianism as such on Ricardian economics was thus non-existent;

(xi) Mill was important as a source of advice for readings in philosophy and politics towards the end of Ricardo's life, but Ricardo at this time had an attitude to Mill which was far from that of a pupil; and yet the encounter between the Utilitarians and Ricardo was productive of important intellectual results, like other encounters the Utilitarians made with Unitarians and other "friends of reason", even if it did not start with doctrines but instead with praxis. 
References

Bain, A. [1882] (1995). James Mill. A Biography. In Mill (1995).

--- (1995). The Collected Works of James Mill. 7 vols. London: Routledge/Thoemmes.

Belsham, Th. (1801). Elements of the Philosophy of the Mind, and of Moral Philosophy. To which is Prefixed a Compendium of Logic. London: Johnson.

Bonner, J. (1995). Economic Efficiency and Social Justice. The Development of Utilitarian Ideas in Economics from Bentham to Edgeworth. Aldershot: Elgar.

Bowring, J. (1834). The Works of Jeremy Bentham. 10 vols. Edinburgh: Tait.

Brougham [1839] (1951-73). Lord Brougham's sketch of Ricardo in Parliament. In Ricardo (1951-73), vol. 5.

Collini, S., Winch, D. and Burrow, J. (1983). That Noble Science of Politics. A Study in Nineteenth Century Intellectual History. Cambridge: Cambridge University Press.

Collison Black, R.D. (1988). Bentham and the Political Economy of the Nineteenth Century. The Bentham Newsletter, 12: 24-36.

Cremaschi, S. (1994). Review of M. Milgate and Sh.C. Stimson, "Ricardian Politics". The European Journal of the History of Economic Thought, 1 (3): 642-624.

Cremaschi, S. (1998) La herencia newtoniana en la economía política del siglo XVIII, in A. Elena, J. Ordóñez, M. Corbi eds., Después de Newton: ciencia y sociedad durante la Primera Revolución Industrial, Madrid: Anthropos.

Cremaschi, S. (1999). A Man from another Planet. David Ricardo and the Unitarian Legacy. Paper presented at the ESHET Annual Meeting, Valencia. Mimeo.

Cremaschi, S. (2000). Les Lumières Écossaises et le roman philosophique de Descartes, in Y. Senderowicz, Y. Wahl eds, Descartes: Reception and Disenchantment, Tel Aviv: University Publishing Projects.

Cremaschi, S. and Dascal, M. 1996. Malthus and Ricardo on Economic Methodology. History of Political Economy 28 (3): 475-511.

Cremaschi, S. and Dascal, M. (1998a). Persuasion and Argument in the Malthus-Ricardo Correspondence, in W.J. Samuels, J.E. Biddle eds, Research in the History of Economic Thought and Methodology. Stamford, Co: JAI Press, 16: 1-63.

Cremaschi, S. and Dascal, M. (1998b). Malthus and Ricardo: Two Styles for Economic Theory. Science in Context 11 (2): 229-54.

Cremaschi, S. and Dascal, M. (2002). The Unitarian Connection and Ricardo's Scientific Style, History of Political Economy 34 (2): 505-8. 
Dascal, M. and Cremaschi, S. (1999). The Malthus-Ricardo Correspondence: Sequential structure, argumentative patterns, and rationality. Journal of Pragmatics 31: 1129-72.

Davis, J.B. (1989). Distribution in Ricardo's Machinery Chapter. HOPE 21.3: 457-80.

de Marchi, Neil B. 1970. The Empirical Content and Longevity of Ricardian Economics. Economica, 37: 257-76.

Depoortère, Ch. (2002). On Ricardo's Method: The Unitarian Influence Examined. History of Political Economy 34 (2): 501-4.

Destutt de Tracy, A. [1803] (1804). Eléments d'idéologie. Première partie. Idéologie proprement dite. Paris: Courcier.

Guidi, M.E.L. (1991). I/ sovrano e l'imprenditore. Utilitarismo ed economia politica in Jeremy Bentham. Roma and Bari: Laterza.

Halévy, E. (1901-4). La formation du radicalisme philosophique. 3 vols. Paris: Alcan.

Henderson, J.P. (1995). The Life and Economics of David Ricardo. Dordrecht: Kluwer.

Hollander, S. (1979). The Economics of David Ricardo. Toronto and Buffalo: The University of Toronto Press.

---. (1985). The Economics of John Stuart Mill. Toronto and Buffalo: The University of Toronto Press.

--- (1996). Notes on a Possible Bentham Manuscript: a Mystery Unresolved, Cambridge Journal of Economics, 20 (5).

---- (1999). Sigot on the Mystery Manuscript: a Reply. Cambridge Journal of Economics, 20 (3): 370-85.

Mack, M.P. (1962). Jeremy Bentham. An Odyssey of Ideas 1748-1792. London: Heinemann.

Milgate, M. and Stimson, Sh. C. 1991. Ricardian Politics. Princeton: Princeton U. P.

Mill, J. (1813). East India Company, Monthly Review, 70: 410-25.

---. (1816). Government. In Mill (1995).

---. [1817]. 1997. History of British India. 10 vols; with notes and continuation by H.H. Wilson. London: Routledge (Reprint of the 1858 edition).

---. [1829] (1995). Analysis of the Phenomena of the Human Mind. In Mill 1995.

--- (1995). The Collected Works of James Mill. 7 vols. London: Routledge/Thoemmes.

Patten, S. (1899). The Development of English Thought, New York: Macmillan.

Ricardo, David. [1817] (1951). On the Principles of Political Economy and Taxation. In Ricardo, (1951-73), vol. 1.

-----. [1928] (1951). Notes on Mr Malthus. In Ricardo (1951-73), vol. 3. 
----. (1955). Notes on Bentham. In Ricardo (1951-73), vol. 3: 226-341.

Ricardo, D. (1951-73). The Works and correspondence. 11 vols. Cambridge: Cambridge University Press.

Ricardo, [Moses]. [1824]. A Memoir of David Ricardo. In Ricardo (1951-73), vol. 10: 3-13.

Rizvi, S. A.T. (1992). Ricardo's Resistance to Utility and the Association of Ideas Debate. Burlington: University of Vermont. Mimeo.

Say, J.-B. (1803). Traité d'économie politique. Paris: Deterville.

Sigot, N. (1999). A Note on Hollander's 'Notes on a Possible Bentham Manuscript: A Mystery Unresolved'. Cambridge Journal of Economics, 23 (3): 371-8.

Schumpeter, J.A. (1954). History of Economic Analysis. New York: Oxford University Press.

Smith, A. (1983). Lectures on Rhetoric and Belles Lettres. The Glasgow Edition of the Works and Correspondence of Adam Smith, vol. 4, Oxford: Clarendon Press.

Stephen, L. [1900] 1950. The English Utilitarians. 3 vols. London: The London School of Economics.

Sraffa, P. (1951). Introduction. In Ricardo (1951-73), vol. 1: xiii-Ixii.

---. (1955). Addenda to the Memoir. In Ricardo (1951-73), vol. 10.

Stigler, G. J. (1950). The Development of Utility Theory I. Journal of Political Economy 58: 307-327.

Thomas, W. (1979). The Philosophic Radicals. Oxford: Clarendon Press.

\section{Abstract}

The paper discusses Ricardo's relationship to Mill and Bentham. It discusses first the origins of the myth of Ricardo's dependence from Bentham through Mill, and Halévy's contribution to the freezing of such a myth. The paper reconstructs what were their shared political commitments and activities and the kind of specific political views and agenda that may be ascribed to Ricardo himself.

The paper discusses then the question of Ricardo's adhesion to Benthamite ethics. It examines fragments in Ricardo's correspondence with Maria Edgeworth and Francis Place, and adds fresh light on the issue by highlighting the partial overlapping between Bentham's ethics and the kind of intuitionism with theological consequentialism that Ricardo had learned from the Unitarian minister Thomas Belsham. 


\title{
I wish to thank Pier Luigi Porta for a number useful suggestions on Ricardo, Marcelo Dascal for suggestions on use of Gricean pragmatics in the reading of texts, and Natalie
}

\author{
Sigot for useful comments on a former draft.
}

\begin{abstract}
${ }^{1}$ On the implications of use of the term "principles" instead of "laws" by Adam Smith see Cremaschi 1998: 88-92.

2 Elie Halévy is aware of the antirealist character of Priestley's epistemology, focused on criticism of causality (See Halévy 1901-4, III: 270-1. Like in best detective stories, he almost detected the crime's weapon and did not realize it. He was excusable, his Franco-centric megalomania notwithstanding, as he could not suspect, about 70 years before publication of Sraffa's Addenda to Moses Ricardo's Memoir, that Ricardo had been conversant for about 23 years with Priestley's main disciple. Piero Sraffa, in turn, did see the crime's weapon, but overlooked it. A few possible implications of that circumstance have been drawn by Cremaschi and Dascal (1996), (2002) and Cremaschi (1999).

${ }^{3}$ But wasn't Dugald Stewart a follower of Reid and Adam Smith and thus a critic of Cartesianism? On this point see Cremaschi (2000).

4 On Stimson and Milgate's reading of Ricardo's political theory see Cremaschi (1994).

${ }^{5}$ For a preliminary rejoinder see Cremaschi and Dascal (2002); a wider account is in Cremaschi (1999).

${ }^{6}$ The discovery of the possible implications of the Unitarian legacy was made by chance while working at a research project on the controversy between Malthus and Ricardo whose focus was the role of pragmatics for understanding the shaping and evolution of theories (See Cremaschi and Dascal 1996, 1998a, 1998b,
\end{abstract} 2002; Dascal and Cremaschi 1999)

7 The review was published in the Anti-Jacobin Review, issue of June 1st 1802. Bain, who seems not to know even the proper title of the book (he mentions it as Elements of Logic and Mental Philosophy) describes it as follows: "He attacks Belsham's definitions, his logic, his order of putting logic before metaphysics, his theory of memory. He attacks the vibrations of Hartley, and praises Reid's arguments against them. He quarrels with Belsham as to the purpose of Locke's Essay, which he calls - 'An achievement of thought, the greatest perhaps on record in the treating of the human mind'. Attacks his selfish theory of morals [sic]: 'it imposes an obligation to be vicious, removes the moral character of the Deity, and renders it impossible to prove a future state'. 'Till you have first proved the moral attributes of God, it is absurd to offer a proof of Revelation. For, however certainly you prove revelation to be the word of God, unless I know that God is true, how do I know that his word is true?" (Bain 1882: $41 \mathrm{fn}$.). Note the mention made by Bain of Belsham's selfish theory of morals; in what sense was Belsham's view of morals 'selfish'? It is clear enough that Bain had no faint idea of the contents of Belsham's book, but also that Mill's reading was hasty. Note also the misplaced emphasis that Mill puts on theological issues when discussing a book of philosophy of mind and logic; it is a clear mark of Mill's troubles with his own choice of abandoning the Calvinist faith; such a discomfort, and the ensuing feeling of guilt, is immediately transferred to an external target, in this case the leader of the most extreme fringe of Christian Enlighteners, that the would-be Reformer James Mill takes as a target in his first publication. Apparently, James Mill was following some Marxist-Leninist handbook of political tactics.

8 See Mack (1962): 151-200; Stephen (1950), vol. 1: 136-42; vol. 2: 45-9; Guidi (1991): 58-72.

${ }_{9}$ Patten wrote that "the peculiarities that made James Mill influential came from the fact that he was a Calvinist by birth and retained through all his life the characteristics for which men of this type are remarkable" (Patten 1899: 314), namely they "are noted for the strict way in which they reason, and for the boldness with which they apply their principles into details. Disliking exceptions and compromises, they readily accept disagreeable conclusions if these seem to be deductions from general principles" (Patten 1899: 315), and "the creed of James Mill was thus Calvinism minus God and charity" (Patten 1899: 316) 10 It is but too obvious that here Belsham was "forerunning" the renowned conclusion of Sidgwick's Methods of Ethics with more than 70 years lead; that is, Sidgwick was repeating Belsham's argument without paying due acknowledgement.

${ }^{11}$ On the importance of taking these pragmatic aspects into account while reading economic texts, see Dascal and Cremaschi 1999.

12 See Sigot (1999); Hollander (1999).

13 See Collison Black (1988); Guidi (1991).

${ }^{14}$ See also Hollander (1985): 27, and Collini, Winch, and Burrow (1983): 112-126. 